\title{
HUMAN RESOURCE PERFORMANCE IMPROVEMENT INTRINSIC MOTIVATION BASED MODEL AND SKILL VARIATION IN TERMS OF INFORMATION COMMUNICATION TECHNOLOGY
}

\author{
Dwi Priyo Adianto ${ }^{1^{*}}$, Widodo $^{2 *}$
}

\section{* Affiliation: \\ ${ }^{1,2}$ Management \\ Postgraduate Programme, Sultan Agung Islamic University}

\begin{abstract}
:
This study aims to test a research model in which the performance of human resources is related to intrinsic motivation, skill variation and information com- munication tecnology. There are as many as 83 respondents who fill out and complete questionnaires about human resource performance, skills variation, intrinsic motivation and information comunication tecnology. Data collection methods by census. The higher the skill variation, the higher the skill variation, the higher the human resource performance, the higher intrinsic motivation, the higher the performance of the human resources performance
\end{abstract}

Keywords : Human Resource Performance, Skill Variation, Intrinsic Motivation, Employee Performance

\section{INTRODUCTION}

Today's development of the banking world is undergoing considerable progress. Since the existence of policy package issued by government and the existence of law UU no. 10 Year 1998 about banking, it has happened easiness to try stimulating growth and competitiveness among banks in Indonesia. Open competition that is getting stiff forces each bank to seek excellence than of other banks, through banking products and by providing facilities and conveniences customers. It causes each bank tries to apply management policy through professionalism in the field of banking.

Bank is a business entity that collects funds from society in the form of both micro and conventional savings and distributes it to society in the form of credit or other forms in order to improve people's standard of living and as an effort to encourage community empowerment.

Based on gap research that is study and phenomenon of implementation skill when using Information Communication 
Technology (ICT), it is said to be still variatif since it is caused by experience and intention of using ICT. So the problem formulation of this study is "How to increase intrinsic motivation and skill variation towards human resources performance in terms of information communication technology."

\section{LITERATURE REVIEW HR PERFORMANCE}

Human Resources are the only source that has sense of feeling, desire, skills, knowledge, encouragement, power and initiative. All of these affect the organization's effort in achieving its goal. However, despite of advanced technology, information development, capital availability and materials adequacy, if it is without human resources that would be difficult for organization to achieve its goal (Edy Sutrisno, 2009).

Werther and Davis in (Edy Sutrisno, 2009) said that human resource is employee who is ready, capable and alert in achieving organization goal. As it is argued that the basic dimension of human resource is its contribution to organization, while human dimension is contribution treatment to it which in turn determines the quality and life ability.

According to Maryoto, (2000: 91), employee performance is work result over a certain period compared with various possibilities, for example standard, target/target or criteria that has been agreed. The indicators are employee work quality, employee work quantity, and contribution to organization. Sherman and Ghomes in Soelaiman (2007: 279) said that "Job performance is the amount of succesfull role achievement" (work achievement/performance is the measurement of attainment). According to Soelaiman in his book Performance Management (2007: 279), he provided an understanding of performance as something that is done and produced in the form of products or services, in a certain period and size by a person or group of people through his skills, abilities, knowledge and experience. Then, he also explained (2007: 283) that employee performance (employee performance) is the level in which employees reach job requirements.

Performance refers to achievement level of tasks that make up an employee's job (Simamora in Agusty, 2006). Performance reflects how well employees meet the requirement of a job. Understanding performance is recording result achieved in performing the specific functions of a job or activity to work during a certain period indicated through the process or way of working and the result achieved. While Byars and Rue in Agusty (2006) defined performance is task completion degree that accompanies one's work. Performance is what reflects how well an individual fulfills a job request. Based on these definitions, it is indicated that performance is a qualitative and quantitative outcome.

\section{SKILL VARIATION}

Increasing human resources 's performance is one of the supporting factors is the level of human resource skill itself. The higher the skill level of an employee, it will be able to improve performance. According to Gordon (1994) the improvement of skill is the ability to operate the work easily and meticulously. This understanding usually tends to psychomotor activity. According to Nadler (1986) the notion of skills is an activity that performs practice 
or can be interpreted as an implication of the activity. And according to Dunnette (2006) understanding of skills is the capacity needed to carry out some tasks that are the bearers of the training and gained experience. Iverson (2001) said that in addition to the necessary training to develop skills, it also requires basic ability ability to do the job easily and precisely. Based on the above understanding it can be concluded that the skill means the ability to operatea job easily and carefully and that requires basic skill (Basic ability). According to Robbins (2000: 494-495) basically skill can be categorized into four, they are: 1). Basic literacy skill that is basic skill that someone posses that must be owned by most people, like reading, writing and listening. 2). Technical skills that is technical expertise of a persone in the development of owned technique, such as counting quickly, operating computer. 3). Interpersonal skills that is a person's interpersonal ability to effectively interact with other people or with partners, such as a good listener, express opinions clearly and work in a team. 4). Problem solving that solves the problem is the process of activities to sharpen the logic, the argument and problem solving and the ability to know the cause, develop alternatives and analyze and choose a good solution.

Studies of Haichao Zheng, Dahui Li, and Wenhua Hou (2011) explained that variations in skills are human resources applying different skills to complete the job, the use of different skills further explains the indicators such as: 1). I have the opportunity to do different things to solve the job. 2). I will use different skills and talents to solve different jobs. 3). I will use my talents to solve different jobs.

\section{H1: The higher skill variation, the higher the intrinsic motivation}

\section{INTRINSIC MOTIVATION}

Motivation of one mover from within one's heart to do or achieve a goal. Motivation can also be said as a plan or desire to lead to success and avoid failure of life. In other words, motivation is a process of achieving one's goal. A person who has motivation means that he has the power to gain success in life.

Motivation can be intrinsic and extrinsic. Intrinsic motivation is when the nature of the work itself that makes a person motivated, the person gets satisfaction by doing the job is not because of other stimuli such as status or money or it could be said someone doing his hobby. While extrinsic motivation is when the elements outside the work attached to the job become the main factors that make a person motivated such as status or compensation.

Motivation becomes a force, or power, or a complex state and a willingness in the individual to move toward a certain goal, both consciously and unconsciously (Makmum, 2003). A person $>$ s motivation can be generated and grows through himself-intrinsically and from the extrinsic environment (Elliot et al., 2000: Sue Howard, 1999). Intrinsic motivation means as the desire of the self to act in the absence of external stimuli (Elliot, 2000). Intrinsic innovation will be more profitable and will provide a stability in learning. Extrinsic motivation is described as a motivation that comes from outside the individual and can not be controlled by the individual (Sue Howard, 1999). Elliott et al. (2000) exemplified the values, rewards, or rewards used to stimulate one's motivation.

What is meant by intrinsic motivation is the motives that become active or functioning and does not need to be stimulated from outside, because in every individual there is an urge 
to do something. Intrinsic motivation comes from the heart of the heart generally because of awareness, for example, an employee is working hard because he realizes that he needs the job to feed his family so that the employees work hard.

According Taufik (2007), the factors that influence intrinsic motivation are:

1. Needs (need) Someone doing activities (activities) because of the factors - needs both biological and psychological, for example, the willingness of the father to work.

2. Hope (expectancy) Someone motivated by the success and the hope of success is a person's self-gratification, success and self esteem improve and move a person toward the achievement of goals.

3. Interest. Interest is a sense of preference and craving for a thing without being told. Indicators of intrinsic motivation menlout Harzberg Luthans (2011) include: 1). Achievements (Success), 2). Recognition, 3). Work it self, 4).Responsibility (Responsibility).

H2: The higher skill variations, the higher the performance of human resources

H3: The higher the intrinsic motivation, the higher the performance of human resources performance

\section{INFORMATION COMMUNICATION TECHNOLOGY}

According to (Krafft, 1999) experience is an accumulation of knowledge. Experience arises through a process of adaptation and accumulation resulting in the crystallization of knowledge.

The Human Capital Theory (Ruderman and McCauley, 1994) explains that if managers have more work experience, the views and mastery of expertise in the field of management are increasing. While economists use employment as a measure for human capital, where types of work tasks are more challenging (Tasmi \& Ohlott, 1988).

Study of Widodo (2008) explained that performance is determined by work experience as measured by length of work within the organization and duration of work on -specific tasks. The experience criteria includes: 1). Managers who have varied work experience within the organization will result in higher performance. 2). Managers who have too long work experience will result in lower performance. It happens because of boredom.

The experience of ICT use moderates the variables of HR capability, motivation and experience on the effectiveness of human resources (Venkatesh et al., 2010). Therefore the proposed hypothesis is:

H4: The higher intrinsic motivation, the higher the performance of human resources with the moderation of experience using ICT.

H5: The higher skill variations, the higher the performance of human resources with moderation of experience of using ICT. 


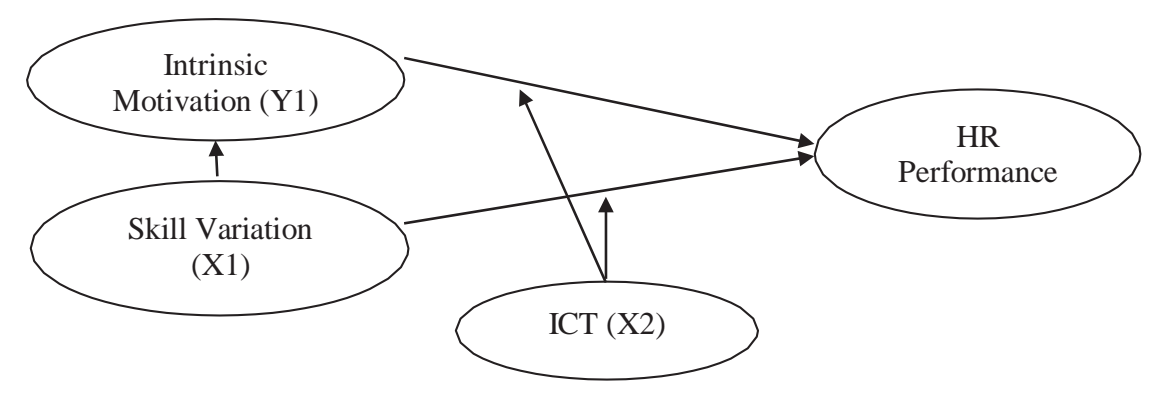

Figure 1. Empirical model

\section{RESEARCH METHOD}

This study is conducted to test the hypothesis with the intention to justify or reinforce the hypothesis with the expectation, it can strengthen the theory used as a foothold. In this case, the research type used is explanatory research or explanation which means explanation, it means that this research emphasizes on the relationship between research variables by testing the description hypothesis contains description but the focus lies in the relationship between variables (Singarimbun, 1982)

\section{DISCUSSION}

\section{VALIDITY TEST}

Validity test in this study is using Product Moment correlation, if the calculation results $r$ count $>r$ table, then the questionnaire valid or valid. Based on calculations with SPSS program can be seen in Table $4.9 \mathrm{r}$ count ( Corrected Item-Total Correlation ) work efficiency variables, ICT usage experience, quality of technology collaboration, use of ICT $>r$ table product moment $(0.383)$. So the questionnaire in this research is valid / valid.

\section{THE INFLUENCE OF PROFESSIONAL COMPETENCE ON HR PERFORMANCE}

Testing second hypothesis, yielding $T$ Statistics $4,983 \geq 1,96$ and $P$ Value $0.000 \leq 0,05$, showed that Professional Competence positively and significantly influence to HR Performance or hypothesis accepted. The role of Inspectorate as an effective Government Internal Supervisor Officials (APIP) can be realized if supported by professional and competent Human Resources (Auditor and Staff Secretariat) with better quality supervision result. Specifically the Auditor must have the education, knowledge, skills and skills, experience, and other competencies required to carry out his responsibilities. Education, knowledge, skills and skills, experience, and other competencies are collective, which refers to the professional skills that auditors need to effectively carry out their professional responsibilities. The results support the results of previous studies. In the study (Dinger et al, 2015) explained that some professional dimensions are related to intrinsic motivation, job satisfaction and job performance.

Table 1. Data Validity Test 


\begin{tabular}{llllll}
\hline No & Variables & Indicator & r count & r standard & Information \\
\hline 1. & Variation & Varket1 & 0.736 & 0.383 & Valid \\
& Skills & Varket 2 & 0.712 & & Valid \\
& & Varket 3 & 0.683 & & Valid \\
2. & & & & \\
& & Useitc1 & 0.834 & 0.383 & Valid \\
& ICT Use & Useitc 2 & 0.792 & & Valid \\
& & Useitc 3 & 0.843 & & Valid \\
3. & Intrinsic & Motin1 & 0.738 & 0.383 & Valid \\
& Motivation & Motin 2 & 0.755 & & Valid \\
& & Motin 3 & 0.648 & & Valid \\
& & Motin 4 & 0.568 & & Valid \\
& & & & \\
& & Kinsdm1 & 0.733 & 0.383 & Valid \\
& HR Performance & Kinsdm2 & 0.714 & & Valid \\
& & Kinsdm3 & 0.625 & & Valid
\end{tabular}

\section{DATA RELIABILITY TEST}

Reliability test on testing using Cronbach Alpha, if Cronbach Alpha >0.6 then the questionnaire is said to be consistent or reliable, (Imam Ghozali, 2002: 153). Based on the calculation with the SPSS program each variable has a value> 0.6 alpha as shown in Table 4.10. So the questionnaire in this research is consistent or reliable.

Table 2. Data Reliability Test

\begin{tabular}{lccl}
\hline No & Variables & Alpha & Information \\
\hline 1. & Skill Variations & 0.779 & Reliable \\
2. & Use of ICT & 0.836 & Reliable \\
3. & Intrinsic Motivation & 0.769 & Reliable \\
4. & HR performance & 0.766 & Reliable \\
\hline
\end{tabular}

\section{CLASSICAL ASSUMPTION TEST}

Multicolinearity assumption test means that between independent variables should not be any correlation. To test for the presence of cholinearity, VIF and tolerance test is used, if the calculation of inflation variance value (VIF) below $10 \%$ and tolerance of free variable above 10\% (Imam Ghozali, 2001) based on the calculation shown in Table 4.11 
Table 3. Multicoleniarity

\begin{tabular}{lclll}
\hline No. & Bound Variables & Free Variables & Tolerance & VIF \\
\hline 1. & HR Performance & Skill Variations & $10.0 \%$ & 1,000 \\
& & Intrinsic Motivation & $10.0 \%$ & 1,000 \\
& \multirow{2}{*}{ HR Performance } & Skill Variations & $10.0 \%$ & 1,000 \\
& & Intrinsic Motivation & $10.0 \%$ & 1,000 \\
& & ModY1X2 & $68.3 \%$ & 1.464 \\
& & ModX1X2 & $98.1 \%$ & 1,019 \\
\hline
\end{tabular}

Heterocedasticity aims to test whether in the regression model there is a variance inequality of the residual one observation to another observation. If the variant of the residual one observation to another observation remains, then it is called homoscedasticity and if different is called Heterocedasticity. A good regression model is Homoscedasticity. How to detect the presence or absence of Heterocedasticity is to look at the plot graph between the predicted value of the bound variable (ZPRED) and its residual (SRESID). Detection of a particular pattern on the scatterplot chart between SRESID and ZPRED where the $\mathrm{Y}$ axis is predicted $\mathrm{Y}$, and the $\mathrm{X}$ axis is the residual.

To test the presence or absence of Heterocedasticity, in Figure 4.1, the scaterplot graphs of the points spread randomly and spread either above or below the number 0 on the Y axis. It was concluded that Heterocedasticity did not occur in the regression model (Gozali, 2001)

Normality test aims to test whether in the regression model the dependent variable and independent variables both have a normal distribution or not.This test uses normal plot $p$. Based on the test shown in Figure 4.2. The figure shows that the residuals are normally distributed and symmetrical in shape, not right or left. In the normal graph of probabilityplots the spreading points coincide around the diagonal this shows normal distributed.

\section{DOUBLE REGRESSION}

Based on multiple regression calculations with Windows SPSS 20.0 Version software, the results are shown in Table 4.12

Table 4. Regression Summary

\begin{tabular}{lllllll}
\hline No. & Bound Variables & Free Variables & T count & B & Sign & Information \\
\hline 1. & Intrinsic Motivation & Skills Variation & 2,786 & 0.296 & 0.007 & Ha Accepted \\
2. & HR Performance & Skill Variations & 0.417 & 0.046 & 0.678 & Ha Denied \\
& & Intrinsic Motivation & 3.922 & 0.399 & 0,000 & Ha Accepted \\
3. & \multirow{2}{*}{ HR Performance } & Skill Variations & 0.417 & 0.046 & 0.678 & Ha Denied \\
& & Intrinsic Motivation & 3.922 & 0.399 & 0,000 & Ha Accepted \\
& ModY1X2 & 9,490 & 0.807 & 0,000 & Ha Accepted \\
& & ModX1X2 & 11,080 & 0.785 & 0,000 & Ha Accepted \\
\hline
\end{tabular}




\section{Skill Variation Effect on Intrinsic Motivation}

The first hypothesis put forward in this research is that if the rate of use of technology increases, then the quality of technology collaboration will increase. Based on calculations with SPSS software, the regression coefficients showed the number of 0,296 means that the higher the skill variety, the higher the intrinsic motivation at the Bank Cluster Pekalongan. Then $t$ count $(2,786)>t$ table $(1,963)$ and significant level of independent variable (skill variation) shows the number of $0,007<0,05$. It means the proposed hypothesis (Ha accepted), ie if skill variation increases, then intrinsic motivation will increase at Bank Mandiri Cluster Pekalongan, supported by empirical data.

Increasing skill variation is a benefit expected by human resources in performing their duties or while doing the job. Skill variations can be effectively utilized if the human resources within a company can use these skill variations well. Therefore it is very important for human resources to understand and predict the usefulness of the system. The adoption of the hypothesis means supporting Venkatesh et al. (2010) suggests that skill variation will increase intrinsic motivation.

\section{Skill Variation Effect on HR Performance}

The second hypothesis proposed in the study is that if the skill variation increases, then the human resource performance will increase. Based on calculation with SPSS software, regression coefficient shows the number of 0.046 means the skill variation is higher, the higher the performance of human resources at Bank Mandiri Cluster Pekalongan. Then t count $(0,417)$ $<t$ table $(1,963)$ and significant level of independent variable (skill variation) shows the number of $0,678>0,05$. It means the proposed hypothesis (Ha rejected), for example if skill variation increases, then the performance of human resources will increase in Bank Mandiri Cluster Pekalongan, supported by empirical data.

Skill variations can be effectively utilized if the human resources within the company can use the skills well. It is therefore very important for the company>s human resources to understand the talent for solving different jobs using the system. The adoption of this hypothesis means that supporting Venkatesh et al. (2010) suggests that skill variation will improve the performance of human resources.

\section{Intrinsic Motivation Effect on Human Resource Performance}

The third hypothesis proposed in the study is that if intrinsic motivation increases, then work efficiency will increase. Based on calculations with SPSS software, the regression coefficient indicates a figure of 0.399 means that the higher the intrinsic motivation, the higher the performance of human resources at the Bank Cluster Pekalongan. Then t count (3.922)> t table (1.963) and a significant level of independent variables (intrinsic motivation) shows a figure of $0,000<0.05$. It means the proposed hypothesis (Ha accepted), ie if the intrinsic motivation increases, then the performance of human resources will increase at Bank Mandiri Cluster Pekalongan, supported by empirical data. 
Intrinsic motivation is a motive that becomes active or functioning does not need to be stimulated from the outside, because in every individual there is an urge to do something. Intrinsic motivation is the individualıs individual human resource that is associated with success, recognition, work itself, responsibility.

Acceptance of the hypothesis means supporting the results of Sue Young Choi>s study, (2010) which showed that intrinsic motivation can improve the performance of human resources.

\section{Intrinsic Motivation Effect on Human Resource Performance with Moderation of ICT Usage.}

The fourth hypothesis proposed in the study is that if Intrinsic Motivation increases, then the performance of human resources will increase with moderation of ICT usage. Based on calculations with SPSS software, the regression coefficients showed the number of 0,046 means that the higher the intrinsic motivation, the higher the performance of human resources by moderating the use of ICT in the Bank Cluster Pekalongan.

Then $t$ count $(0,417)<t$ table $(1,963)$ and significant level of independent variable (intrinsic motivation) with moderation of ICT usage show the number equal to $0,678>0,05$. It means the proposed hypothesis (Ha rejected), ie if the intrinsic motivation increases, the human resource performance will increase collaboration with moderation of ICT use at Bank Mandiri Cluster Pekalongan, supported by empirical data

\section{Skill Variation Skill on Human Resource Performance with Moderation of ICT Usage.}

The fifth hypothesis proposed in the study is that if the level of skill variation increases, the performance of human resources will increase with moderation of ICT usage. Based on calculations with SPSS software, the regression coefficient indicates a figure of 0.399 means that the higher the skill variety, the higher the performance of human resources by moderating the use of ICT in the Bank Cluster Pekalongan.

Then t count (3.922)>t table $(1,081)$ and the level of significant independent variables (skill variation) with moderate use of ICT showed a figure of $0.000<0.05$. Hypothesis proposed (Ha accepted), ie if skill variation increases, then human resource performance will increase collaboration with moderation of ICT usage at Bank Mandiri Cluster Pek alongan, supported by empirical data. With the acceptance of the hypothesis means supporting the results of the study Venkatesh et al. (2010) the use of ICT to moderate intrinsic motivation variables and skill variations with human resource performance

\section{CLOSING \\ Conclusion}

The formulation of the problem in this research is "How to increase model of intrinsic motivation and skill variation towards performance of human resource performance in terms of information communication technology". Based on the hypothesis - a hypothesis that has been developed in this study, the research problems that have been proposed can be justified by the 
testing path analysis (path analysis) has been drafted through this research that the relationship between the variables that affect the performance of human resources consisting of four variables proposed and supported empirically, they are: skill variation, intrinsic motivation, ICT and human resource performance.

\section{REFERENCE}

DL Goodhue, R. T. 2006. Human-Computer Interaction and Management Information Systems: Applications: M E Sharpe Inc.

Fisher, J. D. 2006. The dynamic effects of neutral and investment-specific technology shocks. Journal of political Economy, 114(3): 413-451.

Henry C Lucas . Jr, V. S. 1996. Technology use and performance : a field study of broker workstations. Decision Sciences Vol 30 no. 2(spring, 1996).

Krafft, M. 1999. An empirical investigation of the antecedents of sales force control systems. The Journal of Marketing: 120-134.

Kuncoro, M. 2003. Metode Riset untuk Bisnis dan Ekonomî̂. . Jakarta. : Penerbit Erlangga.

Morgeson, F. D. S. E. H. 2006. The Work Design Questionnaire (WDQ): Developing and Validating a Camprehensive Maesure for Assessing Job Design and the Nature of Work. Journal of Applied Psychology, Vol. 91, No. 6: 1321-1339

Park, T. A. D., Elizabeth E. 2011. Productivity and efficiency impacts of human resources practices in food retailing. Applied Economics, 43(30): 4689-4697.

Ruky Achmad, S. 2002,. Sistem Manajemen Kinerja Untuk Bisnis. Edisi Terjemahan,. Jakarta.: Salemba Empat.

Saleem, J. J., Russ, A. L., Neddo, A., Blades, P. T., Doebbeling, B. N., \& Foresman, B. H. 2011. Paper persistence, workarounds, and communication breakdowns in computerized consultation management. Int J Med Inform, 80(7): 466-479.

Shaikh, Z. A. 2009. Usage, Acceptance, Adoption, and Diffusion of Information \& Communication Technologies in Higher Education: A Measurement of Critical Factors1. Journal of Information Technology Impact, Vol. 9, No. 2, : pp. 63-80, .

Singarimbun, M. 1982. Metode Penelitian Survai.

SP Robbins, A. O., G Roodt. 2003. Organizational Behaviour : Global And Southern African Perspectives (illustrated ed.). South Africa: Pearson South Africa.

Sue Young Choi, H. L., Youngjin Yoo. 2010. The Impact Of Information Technology And Transactive Memory Systems On Knowledge Sharing, Application, And Team Performance: A Field Study. MIS Quarterly Vol. 34 No. 4 (December 2010): pp. 855$870 /$.

Supomo, N. I. d. 2002. metodologi penelitian bisis. Yogyakarta. : BPFE Yogyakarta. . 
Venkatesh, V., Dennis, A. R., \& Brown, S. A. 2010. Predicting Collaboration Technology Use: Integrating Technology Adoption and Collaboration Research. Journal of Management Information Systems, 27(2): 9-54.

Widodo. 2008. Model Pengembangan Evaluasi Strategi. Majalah Ekonomi, Tahun XIX, No. 1 (April 2009).

Zaffar Ahmed Shaikh, I. U. 2009. Usage, Acceptance, Adoption, and Diffusion of Information \& Communication Technologies in Higher Education: A Measurement of Critical Factors. Journal of Information Technology Impact, Vol. 9, No. 2, : pp. 63-80, .

Zeng, H., Dahui Li dan Wenhua Hou. . 2011. Task Design, Motivation, and Perticipation in Crowdsourcing Contests. . International Journal of Electronic Commercee Vol. 15, No. 4 (Summer 2011): pp. 57-88. 